\title{
Impact of Socio-Demographic Characteristic on Employees' Attitudes toward Organizational Change at Vietnam - Hungary Industrial University
}

\author{
Khuong Thi Thu Hai ${ }^{{ }^{*}}$ \\ ${ }^{1}$ Viet-Hung Idustrial University, Hanoi, Vietnam
}

*Corresponding Author: Khuong Thi Thu Hai, Vietnam-Hungary Industrial University, Hanoi, Vietnam

\begin{abstract}
Employees' attitudes toward organization change have strong influence on effective change of organization in many fields, especially in education organizations which are constantly facing the demands of change to meet the demand for effective human resource training for socio-economic development. This study aims to determine the impact of socio-demographic characteristic on employees' attitudes toward organizational change at Vietnam - Hungary Industrial University (VIU), in order to find effective solutions in change management to help the University achieve their targets and mission to 2030. A survey with 152 of the VIU's staff on the attitude of employees on organizational change was done. Results are shown that both Gender, Age, Position, Education and Experience have significant correlation with employees' attitudes toward organization change in VIU.
\end{abstract}

Keywords: Change management; employees' attitudes; organization change; socio-demographic characteristic.

\section{INTRODUCTION}

Nowadays, in the fast challenging business environment, organizations are in steady hunt for a strong strategy which can help them to endure the new global economic order, constructing them to achieve better performance (Ayesha Farooq and Zareen Hussain, 2011). Therefore, change management plays more and more impotant role for organizational development.

Of all factors that related to make high effect for organizations' change management, employees' attitude maybe one of the most important problems. Many researches suggest that the failure of organizational change initiatives can generally be resulted from negative employee attitudes towards the change, unless adequately managed, organizational change initiatives result in feelings of fear and uncertainty, leading to increased stress, reduced levels of trust between employees and management, and declining levels of organizational commitment (Beer \& Nohria, 2000; Elias, 2009; Anthony Andrew, 2017).

To overcome negative attitude to change, organization should prepare a clear arrangement and change awareness among employees in order to generate well planned work surroundings and in proportion work agenda to reduce pressure and insecurity.

The impact of the globalization process, the transition from a commodity economy to a knowledgebased economy and the Fourth revolution in information technology and communication creates more new roles for educations. In this global context, recent reforms in higher education in Vietnam lead to the transformation from the dependency on government funding to the competitive market indicates that universities have to make big and quick changes in university management. These changes often face with a lot of negative attitude of their employee and lead to low effective results.

This study aim to determine the impact of socio-demographic characteristic on employees' attitudes toward organizational change that can help managers group employees according their attitude to organization changes and do suitable solutions for each group to gain best results for change. The experimental study was done at Vietnam-Hungary Industrial University (VIU) by a survey with 152 of the VIU's staff on the attitude of employees on VIU changes in 2011-2016 period. 


\section{LITERATURE REVIEW}

\subsection{Organizational Change}

In some recent decades, researches on organization change have been much interested in, among other areas such as decision making and environmental sense making.

Organizational change is the movement of an organization away from its present state toward some desired future state to increase its effectiveness (Lunenburg, 2010). Change is an unavoidable event arising from the dynamics of environment and it is expected for an organization that desires to grow, achieve its mission, vision and objectives. Organizations have to adapt to the environment to become competitive and stay ahead or at least keep afloat (Rebeka and Indradevi, 2015).

There are different kinds of changes that companies will face during their life time (Mohammad Ali Naghibi and HediyehBaban, 2011). Desler (2007) classified four kinds of change basing on aspects of the organization: its strategy, technology, structure and employees (personnel). Rune Todnem By (2007), summarized the literature review and classified change types based on four dimensions: Change Characterized by the Rate of Occurrence; Change characterized by the rate of occurrence; Change Characterized By How It Comes About and Change Characterized by Scale. He also proposed that Change Characterized by How It Comes About was the most common way. When characterized by how change comes about, there are four types of change: Planned change, Emergent change, Contingency change and Choice change.

Change type can be classified by the essential characteristics that describe the kind and form of change, the qualities that make change what it is and many other criteria. Al-Haddad (2014) indicated when the change type is clearly identified then a manager can choose the most appropriate method to promote change.

\subsection{Employee's Attitude toward Organization Change}

The main focus of previous researches on attitude concerns the nature, function of attitude and how employees mould themselves towards organization change.

Employee's attitudes towards organizational change may be defined as an employee's overall positive or negative evaluative judgment of a change initiative implemented by their organization (Elias, 2009).

According to Stephen and Robbins (2011), attitudes refer to certain regularities of an individual's feelings, thoughts and predispositions to act towards some aspect of his environment.

Attitudes help people to understand the new face of the environment, to assimilate each new item into a set of beliefs that transmit value and guide behavior. In times of change, if the members of the organization embrace the change or believe it will bring benefits, they will probably adapt rapidly to the new system of work. In contrast, negative attitudes towards change may have the opposite effect, decreasing the probability of adaptation to the proposed changes.

There are two types of employee's attitude towards change: One aspect of employees may have a negative attitude towards organizational change and are more likely to refuse to accept the change; and the other aspect of employees have a positive attitude towards organizational change are more likely to hold up to the change.

According to Erich J.Schwarz (2009), employees who have positive attitude towards change in the organization become valuable employees to the organization. Apfelthaler, (2008) revealed employees recognized change with valuable training, which helped in the development of the employees with effective skill.

However, Baumgartner, et al (2008), described that most of the employees are not prepared for change. This situation leads to employee's negative attitude towards change due to the fear about unstable job. They avoid change because they may be unable to cope up with change and may loose their job when organization is downsized or reshuffled with change. Karyn E. Trader-Leigh (2001) projected that change and organization transformation is a rigid effort. Change fails because surroundings are not ready to agree to change and do not well look forward to the strength on 
individual system. Individuals' personal and emotional impact and domination of norms, traditions, compatibility and supporting factors are the reasons to individual resistance to change.

\subsection{Impact of Socio-Demographic Characteristic on Employees' Attitudes toward Organizational Change}

There are many factors that affect employee attitudes towards organizational change have been shown in studies of researchers over the world. However, in this study, author only concentrates on impact of socio-demographic characteristic on employees' attitudes toward organizational change because these factors are consider as antecedent variable that affect on both employees' attitudes toward organizational change and factors that have influence on them.

Socio-demographic characteristics of respondents are commonly used in survey research because different demographic groups can often hold quite different beliefs, thoughts, and perceptions on important matters and such characteristics are helpful to recognize people who behave in similar ways (Alrect \& Settle, 2004). However, the organizational change literature provides contradictory findings about the significance of demographic factors on employee attitude toward the organization change.

In terms of ethnicity, gender, and education, Adams et al. (2002) found that only small differences exist among officers in their receptivity to the philosophy and practices of community policing. There are no differences along ethnic or education lines and only minor differences by gender and number of years in law enforcement. Male officers and officers with more experience in law enforcement are less optimistic about the impact of COP on crime. The findings of this study, according to Adams et al. (2002), showed that although demographic variables are not important regarding officer' attitudes about COP, training and participatory management is effective in a positive way.

Novak et al. (2003) also conducted a similar research in the Kansas City (Missouri) Police Department. This research sought to determine the significance of officer attributes over the officers' acceptance of community policing. It is found that officer characteristics affect their attitudes. For instance, community policing got more support from non-white officers. Officers who had a problem solving role orientation were more likely to support community policing. As expected, officers who believe that people do not respect the police had lower attitudes toward community policing. However, officers' level of education, desire for autonomy, and rank failed to display significant results. Novak et al. (2003) provided one possible explanation for the lack of a relationship between rank and support for community policing: middle managers might view community policing as a loss of job authority.

Cummings (2014) also found employees with different gender and education has significant differences in attitudes toward organizational changes. In particular, male employees tend to respond more positively to organizational changes, and highly-educated (postgraduate) staffs have a more positive attitude and willingness to accept changes are higher.

\subsection{Related Researches in Educational Organization}

The education environment is constantly changing, and the school organization must adapt to these forces in order to remain relevant and effective (Blankstein, 2010). That requirements of change lead a lot of change in education organization: change in the physical environment, change in the curriculum, change in faculty and staff, change in the student body, unexpected change, and most importantly change that can bring about vast improvements in a school district, community college, or university.

According to Grant (2003), managing organizational change in higher education is more multifaceted in other organizations. A long tenure with the university does not necessarily mean that employees identify enough with the institution to have a positive attitude towards change as Bartels, Pruyn, and Jong (2009) suggested. Satisfaction and cooperation with their current job because of job longevity was not the case for the employee considering early retirement. Employee resistance to the change did not reveal the experience in the interviews.

No matter how effective a change is, faculty and staff must be motivated to change. Creating this kind of motivation is "the responsibility of leadership" (McBride, 2010). For organizations to overcome resistance to change, stakeholders at all levels must become involved in the process of change. Even 
as administrators reach out to resistors, administrators must also stay linked with the "adaptors" (McBride, 2010), those members of the faculty and staff who are committed to new ideas, methods, or devices. It is important to remember that resistant faculty and staff can negatively impact an institution's ability to implement change. Resistance can keep an institution of learning from continued growth whether the resistance is rooted in the contagious effects of cynicism or not. Regardless, institutional leaders of higher education are encouraged to "not ignore or leave behind those resistant to change" (McBride, 2010).

About impact of socio-demographic characteristics of employee, Clarke et al. (1996) found that older faculty, tenured faculty males, and full professors were all more likely to resist change than their counterparts. Furthermore, tenured faculty were more likely to resist a policy requiring all faculty to advise the same number of students, males were more likely to resist a policy requiring students to take a course to enhance multi-cultural awareness, full professors were more likely to resist a policy requiring faculty to attend grant writing and publication workshops, and younger faculty were all more likely to resist a policy setting limits on outside consulting opportunities. In higher education organizational change resistance is the result of the feelings that faculty professionalism is being called into question and changed.

\section{Study space}

As analyzing many previous studies, researchers over the world including Vietnamese researchers, have been taken many studies on employee's attitude toward organizational change in many aspects: Definition, classification and role of organizational change, employee's attitude toward organizational change and factors effecting employee's attitude toward organizational change; managing and implementing organization changes. These theoretical and practical studies have provided a solid foundation for managers in managing organization to adapt to the more and more quick change of environments.

However, there are very few previous studies that analyze in detail about factors effecting employee's attitude toward each type of organizational changes, especially studies in education, in Vietnam. So, research on determining employees' attitudes toward organizational change at VIU, and impact of socio-demographic on employee's attitude toward VIU change in order to find effective solutions in change management to help the University achieve their targets and mission to 2030, can be consider as a new significant study both in theory and practice.

\section{CONCEPTUAL FRAMEWORK}

To achieve the research objective, and depend on the literatures that explain above the researcher will use the following conceptual framework.

\section{Independent Variable Dependent Variable}

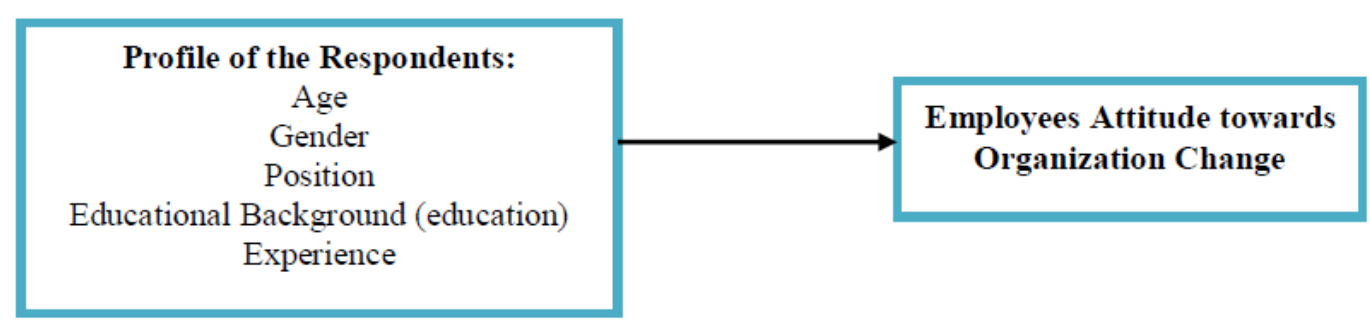

Figure1. Conceptual framework

Dependent variable of this study is Employee attitude toward VIU changes (using 5 point Likert scale: 1. Strongly disagree 2: Disagree; 3 . Neutral; 4 . Agree; 5 . Strongly agree) are code as scale variables).

Profile Variables including Age, gender, Position, Education and Experience are code as Norminal variables and propose to have relationship with Employee attitude toward VIU changes. Regression by SPSS and STATA is use to test this hypothesis and explore the relation between these variables.

\section{Methodology}

The population of this survey is 278 employees including managers, lecturers; office staffs in VIU who are working at VIU. 
The respondents of this study are employees at VIU.

The sample size: The sample size of population 278 employees according to Slovin fomular (with error $\Delta=0.05$ ) was about 160 .

The sampling procedure that is used is cluster sampling and it is a probability sampling procedure therefore all elements had an equal opportunity of being included in the sample.

Research instrument: A "Survey questionnaire" is a tool for collecting data for research. Survey questionnaires consist of 2 parts: Part I is the profile of the respondents including Age, gender, Position, Education and Experience. Respondent answers the question by chosing a most suitable given selection in questionnaire. Part II is assessment of the respondents about the Employees attitudes toward organizational change in VIU.

Data gathering procedure: self-made questionnaire

Statistical treatment: The statistical SPSS and STATA software are then used to run the data.

\section{Results}

\subsection{The Demographic Profiles of the Employees}

The respondents are classified by various demographic characteristics, including gender, age, job position, highest level of education and working experience or number of working years. Table 1 presents the details on frequency and percentages of each group.

Table 1. Profile of respondents

\begin{tabular}{|c|c|c|c|}
\hline & Freq & Percent & Cum \\
\hline \multicolumn{4}{|l|}{ Gender } \\
\hline Female & 64 & 42.11 & 43.24 \\
\hline Male & 88 & 57.89 & 100 \\
\hline \multicolumn{4}{|l|}{ Age } \\
\hline $25-35$ years old & 40 & 26.32 & 26.32 \\
\hline$>35$ years old & 112 & 73.68 & 100 \\
\hline \multicolumn{4}{|l|}{ Job position } \\
\hline Lecturer & 80 & 52.63 & 52.63 \\
\hline Vice Rector/higher position & 60 & 39.47 & 92.11 \\
\hline Managing staff & 12 & 7.89 & 100 \\
\hline \multicolumn{4}{|l|}{ Education } \\
\hline Doctor & 12 & 7.89 & 7.89 \\
\hline Master & 104 & 68.42 & 76.32 \\
\hline University & 36 & 23.68 & 100 \\
\hline \multicolumn{4}{|l|}{ Experience } \\
\hline $1-5$ years & 8 & 5.26 & 5.26 \\
\hline 6-10 years & 44 & 28.95 & 34.21 \\
\hline $11-15$ year & 72 & 47.37 & 81.58 \\
\hline More than 15 years & 28 & 18.42 & 100 \\
\hline Total & 152 & 100 & \\
\hline
\end{tabular}

In 152 respondents, the vast majority (58\%) were male, mostly faculty or holding management positions; over $70 \%$ of the age group over 35 and nearly $95 \%$ have been working in VIU for more than 5 years.

\subsection{Employee Attitude to VIU Change}

Table2. Employees' attitude toward organizational changes in structure

\begin{tabular}{|l|l|l|l|l|l|}
\hline \multirow{2}{*}{ Employees' attitude } & \multicolumn{5}{l}{ Employees' attitude toward organizational changes } \\
\cline { 2 - 5 } & Structure & Management & Pesonel & Postion & Repqiurement \\
\hline Strongly agree & $13.16 \%$ & $10.53 \%$ & $13.16 \%$ & $7.90 \%$ & $2.63 \%$ \\
\hline Agree & $42.11 \%$ & $57.89 \%$ & $47.37 \%$ & $44.74 \%$ & $65.79 \%$ \\
\hline Neutral & $42.11 \%$ & $26.32 \%$ & $34.21 \%$ & $39.47 \%$ & $26.32 \%$ \\
\hline Disagree & $2.63 \%$ & $5.26 \%$ & $0.00 \%$ & $2.63 \%$ & $5.26 \%$ \\
\hline Strongly disagree & $0.00 \%$ & $0.00 \%$ & $5.26 \%$ & $5.26 \%$ & $0 \%$ \\
\hline
\end{tabular}


In general, most of employees show their positive attitude towards changes of organization, management, personnel, position and requirements. Only very small percent employees that have negative attitude towards changes. 2.63\% disagree and $42.11 \%$ are neutral to changes of organization; $5.263 \%$ disagree and $26.32 \%$ neutral to changes of management; $5.263 \%$ disagree, $34.21 \%$ neutral to changes in personnel; $5.263 \%$ disagree and $26.32 \%$ neutral to changes in requirement.

\subsection{Impact of Socio-Demographic on Employee's Attitude toward VIU Change}

Table 2 shows the result of ANOVA test on the difference in attitudes of employees towards organizational changes among those belonging to two gender. The value of Sig $<0.024$ implies that there are a difference in the attitude of two gender.

Table2. ANOVA test on gender

\begin{tabular}{|l|l|l|l|l|l|}
\hline & Sum of Squares & Df & Mean Square & F & Sig. \\
\hline Between Groups & 2.086 & 1 & 2.086 & 5.169 & .024 \\
\hline Within Groups & 60.537 & 150 & .404 & & \\
\hline Total & 62.623 & 151 & & & \\
\hline
\end{tabular}

Similarly, ANOVA test on age also reveals a Sig. value $<0.04$. It also implies that people of different age groups have different attitude towards organizational changes.

Table3. ANOVA test on age

\begin{tabular}{|l|l|l|l|l|l|}
\hline & Sum of Squares & Df & Mean Square & F & Sig. \\
\hline Between Groups & 3.407 & 1 & 3.407 & 8.631 & .004 \\
\hline Within Groups & 59.216 & 150 & .395 & & \\
\hline Total & 62.623 & 151 & & & \\
\hline
\end{tabular}

Table 4, 5 and 6 on the results of ANOVA test on position, education and experience. All show that people belonging to different groups of position, education and experience have different attitude towards organizational changes.

Table4. ANOVA test on position

\begin{tabular}{|l|l|l|l|l|l|}
\hline & Sum of Squares & Df & Mean Square & F & Sig. \\
\hline Between Groups & 7.900 & 2 & 3.950 & 10.756 & .000 \\
\hline Within Groups & 54.723 & 149 & .367 & & \\
\hline Total & 62.623 & 151 & & & \\
\hline
\end{tabular}

Table5. ANOVA test on education

\begin{tabular}{|l|l|l|l|l|l|}
\hline & Sum of Squares & Df & Mean Square & F & Sig. \\
\hline Between Groups & 2.487 & 2 & 1.244 & 3.081 & .049 \\
\hline Within Groups & 60.136 & 149 & .404 & & \\
\hline Total & 62.623 & 151 & & & \\
\hline
\end{tabular}

Table6. ANOVA test on experience

\begin{tabular}{|l|l|l|l|l|l|}
\hline & Sum of Squares & Df & Mean Square & F & Sig. \\
\hline Between Groups & 6.137 & 3 & 2.046 & 5.360 & .002 \\
\hline Within Groups & 56.486 & 148 & .382 & & \\
\hline Total & 62.623 & 151 & & & \\
\hline
\end{tabular}

However, while ANOVA test can check on whether there is difference on attitude of employees by each demographic factors. It cannot explain whether this difference is caused by those factors and give evaluation on impact for attitudes of employees. This weakness can be supplemented by using regression which is initiated on STATA for this study.

Table 7 demonstrates the regression to examine the correlation between demographic factors and the belief on the success of the change program. In overall, all demographic factors have statistically significance to the belief of effectiveness and willingness to support the change programs at different extent.

As seen in the Table 7, the higher position staffs are about $44 \%$ more pessimistic on the effectiveness of the programs. It could be partly explained that lower positions staffs have higher readiness to 
change and might not be a very surprising results. While regarding to education factor, higher education staffs show more willingness to support to the change program. This results is similar to the finding of Hechanava (2003) which reveals that in order to make change valuable, employees need to feel sufficiently skilled and knowledgeable to reduce panic and doubt.

Table7. Difference on the employees' attitude towards organizational changes assessed according to demographic profile

\begin{tabular}{|l|c|c|}
\hline \multirow{3}{*}{ Gender } & Belief of effectiveness & Willingness to support \\
\hline \multirow{2}{*}{ Age } & -0.232 & -0.223 \\
\cline { 2 - 3 } & $(2.14)^{* *}$ & $(1.96)^{*}$ \\
\hline \multirow{2}{*}{ Position } & 0.162 & 0.262 \\
\hline \multirow{2}{*}{ Education } & $(1.22)$ & $(1.88)^{*}$ \\
\hline \multirow{2}{*}{ Experience } & -0.443 & -0.219 \\
\hline \multirow{2}{*}{${ }_{\text {cons }}$} & $(5.32)^{* * *}$ & $(2.52)^{* *}$ \\
\cline { 2 - 3 } & $(1.40)$ & 0.414 \\
\hline $\mathrm{R}^{2}$ & 0.323 & $(4.47)^{* * *}$ \\
\hline $\mathrm{N}$ & $(4.08)^{* * *}$ & -0.184 \\
\cline { 2 - 3 } & 2.032 & $(2.22)^{* *}$ \\
\cline { 2 - 3 } & $(4.29)^{* * *}$ & 3.253 \\
\hline
\end{tabular}

Gender, one again, shows their impact on the attitude to organizational changes. The role of gender difference in this study is consistent with the conclusion in the study of Acker (1990) that organizational structure is not gender neutral.

Both age and experience also show statistically significant difference in the belief of the effectiveness and willingness to support of the program. This is quite similar to the common sense that age groups and experience may have different view on changes. However, the education have a positive impact on willingness to support the change. It is explained that higher education is around $41.4 \%$ more likely to provide aid to organizational change. The difference in the attitude among employees with different education implies the fact that the role of higher education is more specific and important in an educational organization like the industrial Viet - Hung university where education of employees have significant impact on their responsibilities as well as university' treatment to them.

\section{CONCLUSiON}

Basing on the research results, managers of VIU need concern on these following problem when making the university operation plan for change with the following proposal:

Number of negative attitude respondents is quite small, but the influences of them to VIU is not small, expressed in its effect on the low efficiency of university's innovation. So the University really need solution to deal with bad attitude and behavior with university's change.

Socio-demographic factors have a lot of effects on employees' attitude toward VIU change in both positive and negative side, especially, age and education of staff have a lot of effects on change effectivity. So when implementing the change in VIU, managers need to anticipate the react of employees with different profile to propose suitable solution for each group in each development period.

\section{REFERENCES}

[1] Ayesha Farooq and Zareen Hussain, Strategic change management: The challenges faced by organizations. 2011 International Conference on Economics and Finance Research IPEDR vol.4 (2011) IACSIT Press, Singapore.

[2] Beer, M., \& Nohria, N, Cracking the code of change Harvard Business Review, 78, 133-141, (2000).

[3] Elias, S., Employee commitment in times of change: Assessing the importance of attitudes toward organizational change, Journal of Management, 35(1), 37-55.

[4] Anthony Andrew, Influence of Employee Attitude on Employee Readiness for Organizational Change. Asian Journal of Economics, Business and Accounting, 5(1): 1-11, (2017).

[5] Lunenburg. Fred C , Forces for and resistance to organizational change, National Forum of educational administration and supervision Journal, Vol. 27, Issue 4, (2010). 
[6] Rebeka, E. and R. Indradevi. A study on perception of employees during change in an organization, Mediterranean Journal of Social Sciences, Vol. 6, No. 1, 72-79, (2015).

[7] Mohammad Ali Naghibi and Hediyeh Baban, Strategic change management: The challenges faced by organizations, 2011 International Conference on Economics and Finance Research IPEDR vol.4, IACSIT Press, Singapore, 542-544, (2011).

[8] Desler, G., Management Principle and Practices for tomorrow's Leaders, 3rd ed, United States of America: Haughton Mifflin (2007).

[9] Rune Todnem By, Organisational change management: A critical review, Journal of Change Management, 5(4), 369-380, (2007), Doi: 10.1080/14697010500359250, (2007).

[10] Al-Haddad, Serina, Successful Organizational Change: Aligning Change Type With Methods, Electronic Theses and Dissertations (2014).

[11] Stephen P. Robbins \& Timothy A. Judge, Organizational Behavior, 14th edition, Pearson Education, (2011).

[12] Erich J. Schwarz, The effects of attitudes and perceived environment conditions on students, Entrepreneurial intent, vol. 51, 272-291, (2009).

[13] Apfelthaler, G. et al., Global entrepreneurship monitor Austria 2007, FH. Joanneum and university of Graz, Graz, (2008).

[14] Baumgartner, H., Pieters, R., \& Bagozzi, R. P.. Future-oriented emotions: Conceptualization and behavioral effects. European Journal of Social Psychology, 38: 685-696, (2008).

[15] Karyn Trader-Leigh, W., Resistance to organizational change: The role of cognitive and affective processes, Leadership \& organization development journal, vol. 22, Iss. 8, 372-382.

[16] Pamela L. Alreck, Robert B. Settle (2004), The Survey Research Handbook. Third edition. McGraw Hill, New Delhi (2004).

[17] Adams, R. E., Rohe, W. M., \& Arcury, T. A., Implementing community-oriented, policing: Organizational change and street officer attitudes. Crime \& Delinquency 48, 399-430 (2002).

[18] Novak, K. J., Alarid, L. F., \& Lucas, W. L., Exploring officers' acceptance of community policing: Implications for policy implementation. Journal of Criminal Justice, 31, 57-71 (2003).

[19] Cummings, T.G.; Cummings, C (2014). Appreciating organization development: A comparative essay on divergent perspectives. Hum. Resthe, 25, 141-154, (2014).

[20] Blankstein, A. M. (2010). Failure is not an option: 6 principles for making student success the only option (2nded.). Thousand Oaks, CA: Sage, 2010.

[21] Grant, K., Making sense of education change at Thistle College: The existence of witchcraft, witches and shamans. International Journal of Educational Management, 17(2), 71-83, (2003).

[22] Bartels, J., Pruyn, A., \& de Jong, M., Employee identification before and after an internal merger: A longitudinal analysis. Journal of Occupational and organizational Psychology, 82(1), 113-128 (2009). Doi: 10.1348/096317908X283770

[23] McBride, K., Leadership in higher education: Handling faculty resistance to technology through strategic planning [Electronic version]. Academic Leadership, 8(4), 39, (2010).

[24] Clarke, J., Ellett, C., Bateman, J., \& Rugutt, J. Faculty receptivity/resistance to change, personal and organizational efficacy, decision deprivation and effectiveness in research I universities. Paper presented at the Twenty-first Annual Meeting of the Association for the Study of Higher Education, Memphis, (1996).

[25] Hechanova, R.et al., Antecedents and consequences of employees, adjustment to oversea assignment: A meta - analytic review, Applied psychology: An International Review, vol.52, Iss.2, 213 - 236, (2003).

[26] Acker, J, Hierarchies, jobs, bodies: A theory of gendered organizations. Volume 4(2), 139 - 158 (1990). https://doi.org/10.1177/089124390004002002

\section{AUTHOR'S BIOGRAPHY}

Khuong Thi Thu Hai is a lecture from the Vietnam-Hungarry Industrial University.

Citation: Khuong Thi Thu Hai. “ Impact of Socio-Demographic Characteristic on Employees' Attitudes toward Organizational Change at Vietnam - Hungary Industrial University" International Journal of Managerial Studies and Research (IJMSR), vol 6, no. 5, 2018, pp. 1-8. doi:http://dx.doi.org/10.20431/23490349.0605001.

Copyright: (C) 2018 Authors. This is an open-access article distributed under the terms of the Creative Commons Attribution License, which permits unrestricted use, distribution, and reproduction in any medium, provided the original author and source are credited. 